\title{
Study of Tital Power Projects in the UK, with the exception of the Severn Barrage
}

\author{
Dr T.L. Shaw
}

Director, Shawater LId, UK

\section{INTRODUCTION}

The UK has many estuaries with high tides, some higher than Lit Rance. As at Rance and other locations in France, many tide mills were built in the UK as long age ts the 12 th Century. Early in the present Century, engineers from the UK, France and other countries studied the possibility of constructing major barrages to generate electricity. The Severn Estuary received close attention because of its great cnergy potential and its focation close to industry and a large population.

However, when this scheme was actively promoted in the 1920 s there was high national unemoloyment and the scheme was politically unpopular with the nearby coal industry who viewed it as bcing in competition with their power station market. This reaction also probably deterred serious interest being given to other possible sethernes in the UK at that time, and it was not until the sherply contrasting circumstances of the 1970 s arrived that the country again seriously considered the energy potential of its tides.

By that time the Rance scheme had been commissioned and was generally working well. However, a new factor had begun to emerge, namely concen about the envirommentat conseguences of atl forms of development, including power stations. The effects of the lance project were, of course, considered when it was being designed, though much of the basic scientisic information needed to make predictions: was not then available.

Etude des projets marémoteurs en Grande-Bretagne, à l'exception du barrage de la Severn La Grande-Bretagne comporte plusieurs estitaires pouvant être équipés de barrages et d'usines marémo irices et plisieurs projets ont été étudiés entre la fin des années 60 et la privatisanion de lindustrie électrique en 1989

Cinq projets se sont révélés plus prometteurs que les autres:

- l'esinaire de Conwy au nord du Pays de Galles, pour lequel l'étude a conclu que la réalisation n'entraînerait pas trop de problèmes écologiques.

- Duddon, un peu plus au nord, qui n'apparât pas comme intéressant sur le plan économigue,

- Loughor, au sud du Pays de Galles, de petite taille; pour lequel on n'a pas fait de etudes poussées de conséquences êcologigues.

- Mersey, près de Liverpool, le plus important projet (700.MW) qui a le plus de chances d'être réalisé,

- l'estuaire de Wyre, entre Duddon et Mersey, pour lequel le coût sèmble prohibitif.

Les conditions économiques au tournant des années 80 sont largement responsables de l'absence de construction de ces usines, le coût de production du $k$ Wh étant perçu conme deux fois plus élevé que s'il provient d'une centrate classique Evidemment, ce coût tient compie des mestires à prendre pour la protec tion de l'environnement 
The Maritime Laboretory at Dinurd, which has been and remains so prominent in monitoring and assessing the results of the Rance project, contributed much to those studies. In the $i K$, lack of a similar reason to stthdy estuarine ecology in the context of tidal power meant that this subject was not seriously pursucd until completion of Rance stimulated interest in the ecological effects of the Sevem scheme in the late 1960 s [1].

The CK's interest in tidal power increased steadily from that time urtil its electricity industry was privatised in 1989. Since then, the cconomics of hamessing this source have remained unfavourable, a situation unlikely to improve until either the basic cost of producing fossil fuets or the environmental cost of buming them change radically.

During the 20-yeat period of the 1970 s and 1980s, the UK Government initiated investigations of the technical. economic and environmental implications of tidal power barrages in many of the UK's more suitable estuaries. The butk of this work centred on the large project which has been favoured for the Severn Estury since the mid-1960k. However, many smaller schemes in other estuaries were also studied, initially in outline [2].

The five projects shown to be most promising were then studied in more detail. Their names, locations and expected power outputs are given in frgmte 1 . They are all on the west coast of the UK, where the highest lidal ranges occur. The largest of the five schemes is on the Mersey Estuary in Liverpool, and the smallest is on the Loughor Estuary in South Weles. The main difference between these schemes is the size of the basin creatcd by the barrage, hence the volume of water which would pass through the turbines

The results of the UK studies show that there is a strong correlation between the energy and economic potentials of tidal power barrages. Furthermore, although the smaller schemes are arguably less environmentally damaging than the larger ones, their effects on a unit-cnergy basis cause concern.

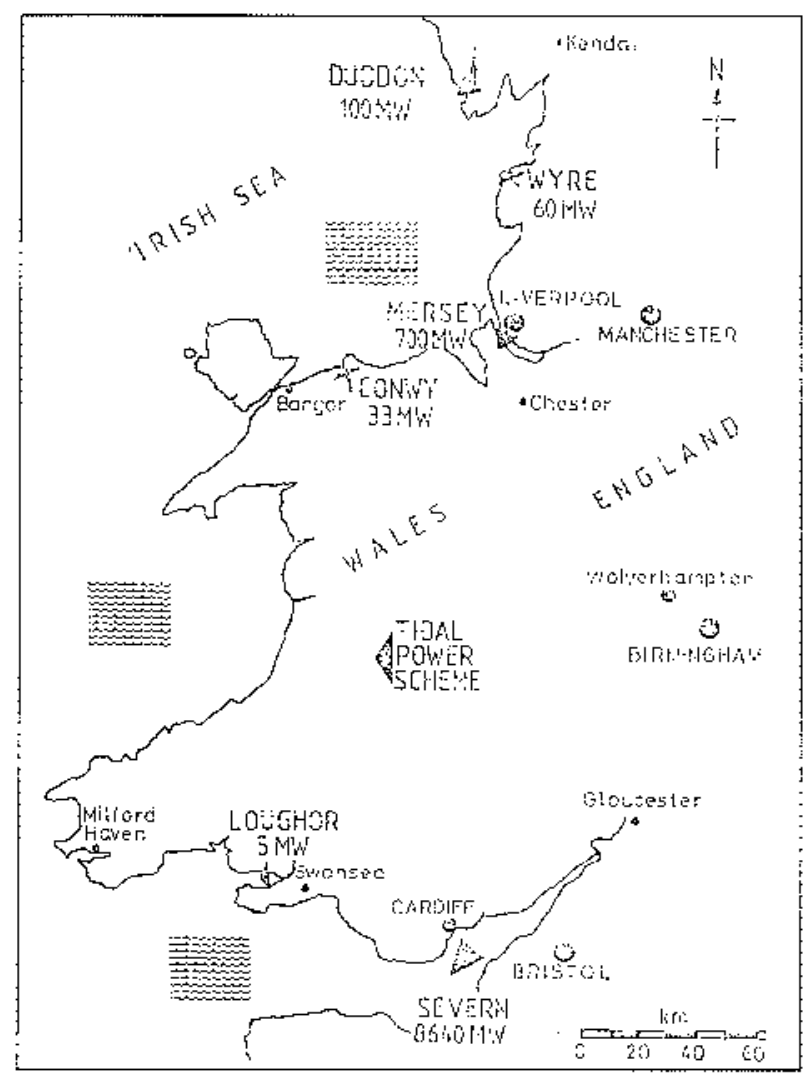

1. Genral location of various sites
The purpose of this paper is to outine the work done on these five sctemes. The results of the more comprehensive studies caried out for a Sevem Barrage are described in the previous paper presented at this Conterence by Dr. Kirby.

\section{II — SOME BASIC PHYSICAL CHARACTERISTICS}

It is generally known and understood that the design of the Rance Barrage was influenced by the fact that it was promoted in the 1950s when the slectricity network in Brittany was relatively weak. However, by the ime it was commissionted in 1996, major developments to the network to support France's expanding naclear programme were in progress. Simitar growth in the UK's electricity network was atso taking place at that time, though the resources available meant that this was based on the coal, oil and nuclear indus. tries rather than on muclear alone.

The situation facing the design of tidat barrages in the LK in the $1970 \mathrm{~s}$ was therefore quite different from that contronting the designers of the Rance scheme in the 1950s. As a result, the design of the Britisti and other more recent tidal schemes is not like Rince. Instead of two-kidy generation and two-way pumping. the technically simpler. more economic but less versatile one-way system involving ebb generation and, probably, flood pumping has generally been preferted. These systems are illustrated in fignte 2 and show that, compared with Rance, the simpler sy'stem gives:

- a smaller but more consistent range of water levels in the basin ;

- a lower high water level ;

- a more regular tidal rhythm.

One of the principal tasks of the Rance Barrage was to provide a platform for research into all aspects of tidal power. To do that it was essential that it could be operated flexibly over a wide range of pumping and genterating scenarios. The fact that, as a result of early research, the ebb gcreration and flood pumping modes are now most ofter used has been recognised in the studies of possible barrage schemes done in the UK and elsewhere

There are several teasons for this preferred mothod of operation. Onc is cconomics. Another is that Rance has shown that the environmental effects of a tidal power scheme depend on its design and how it is operated. The variations in water fevels and eurrents which then occur compared with those of the natural regime and the resultant changes to salinity and sediment movements are clearly affected to a significant degree by the design of a scheme and how it is used. As a result, the LK's preference for abb generation (with or withoul pumping) means that the tidal regimes of the British schemes which have recently been sturdied would be affected as follows:

- the water level in the diceper part of the basin area would not fall below the former fuid-tide level;

- any pumping would be limited to that which would create a maximum level similar to the astronomic maximum in the main basin area (The higher natural astronomic levels which occur further upstream would therefore be reduced because the responsible surge effect would be smaller) ;

- high (and low) tide levels immediale seaward of the barrage would be slightly reduced (increated); these effects diminishing with distance seawards;

- the strengths of the currents would generally be reduced but close to the turbines and sluices could be increased; - the directions of the currents near the barrage would be changed but otherwise would be litule affected.

These hydrodynamic implications for the tidal regime have many cnvironmental consequences. Also important is the effect of the presence of a bartage on the wave climate in the estuary because this is likely to influence the sediment regine and its associated ecosystems along coastal margins. 
Mathematical modelling lechniques allow these changes to be predicted accuratcly. It is straightforward to add salirity into a model, and the same techniques permit the dispersion and degradation of effluents from point and distributed sources to be simulated.

Scdiment movements can also be predicted by modcls, though non-cohesive sands are nore readily represented than time-grained cohesive muds. Studies of the pre-barrage current and wave regimes will help to explain the locations in which fine sediments occur, but a detailed knowledge of the structure of the material present in any estuary will be needed to give confidence in forecasts of with-barrage conditions.

\section{D ECOLOGICAL EFFECTS OF FIVE PROPOSED UK BARRAGE PROJECTS}

Figure $I$ shows the localions of the five projects (excluding the Scvern) reported here. The schemes are shown on figures 3-6. The pliysical effects of each project would be as given in Section ?. Fach estuary has extensive sand deposits towards its seaward limits, with fine sediment in more up. river and sheltered areas. The wider estuaries (e.g., Conwy and Duddon) are more exposed to wave action, hence their sediment regimes mainly comprise sand: fine material is more Iocalised. The Mersey is similar towards its seaward limit but, because the site proposed for that barage is well upstream within the tidal river reach, the environment which it would affeet is principally muddy. The sites of the other two barrages are málinly sandy.

\subsection{Conwy Barrage ([3], fig. 3)}

The historic town of Conwy looks out over the Conwy estuary from within a fine stone wall. Its castle occupies a prominent focation beside the estuary and is popular with visitors. The setting of the town and estuary have been nutionally rec. ognised as an "Area of Outslanding Natural Beauty". 'The location chosen for the barrage would make it a feature within this setting. Its design and operation had to recognise. this constraint.

In addition to the tidal conditions referred to in Section 2, the Conwy Estuary is low-lying and hence subject to flood. ing from a combination of high tides and large river hows. The barrane study made the assumption that the scheme must not increase this risk. However, figure? shows that although a barage need not raise high tide level landward of

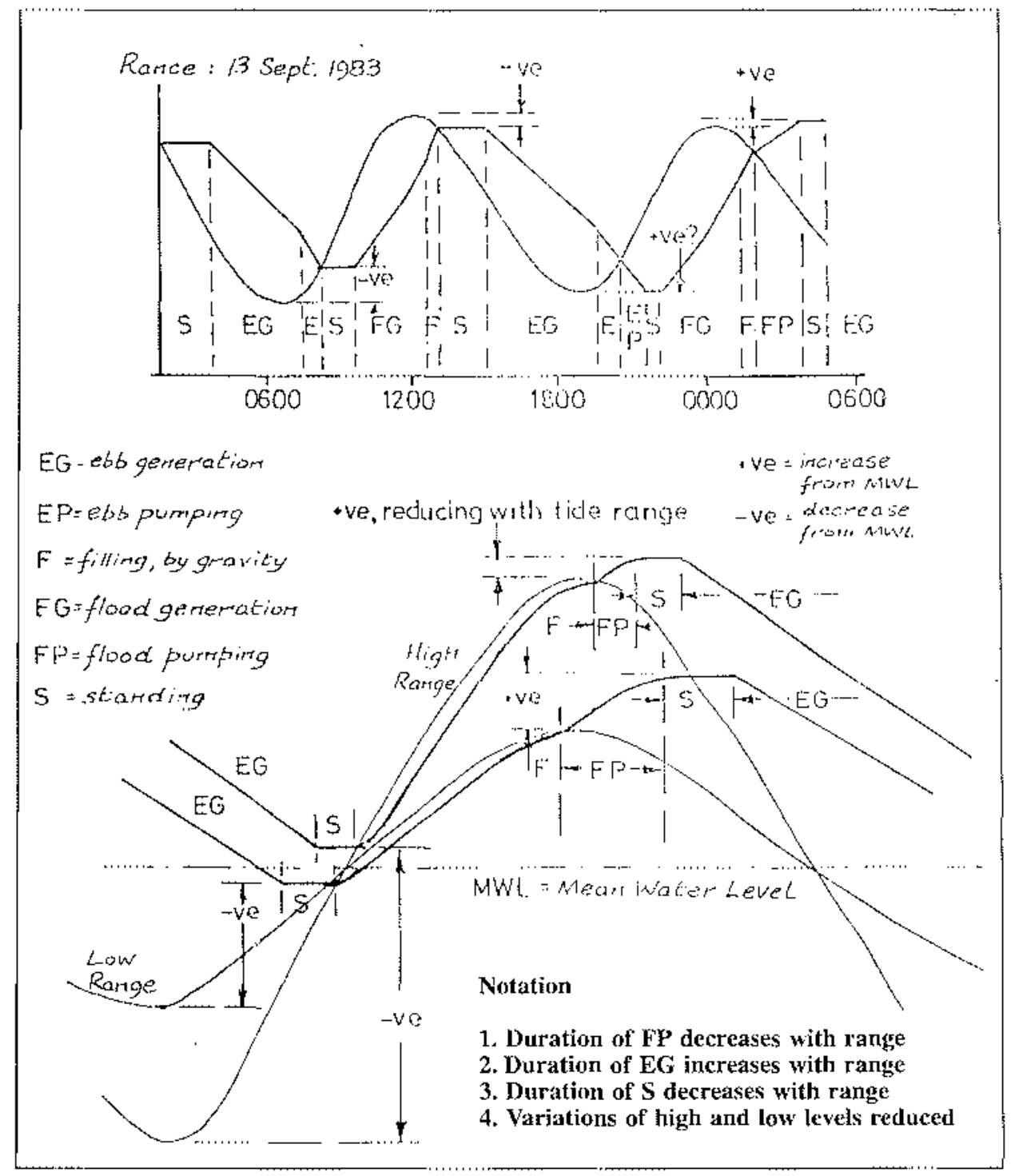

2. Working curves at la Rance tidal power station. 
the barrage, it will increase the time for which high water is mantained. In order nol to magnify the risk of flooding, action would have to be taken to release water early from the basin when river flows are high.

The low-lying areas around the Conwy Estuary rely upon gravity drainage to maintain a reasonable water table level. The efficiency of the existing drainage system would be threatened by extended high tide periods. If this efficiency is not improved, a barage would raise the water able in thest areas. Some pumping would be needed to maintain the itattes quo.

Although sand is ptedicled to enter the basin from seaward, it was estimated that it would take about 200 years for half the capacity of the basin to be filled. This extimate docs not take into account the way in which storms mobilise existing banks of sand in the onter estuary and how this would be redistributed.

The burrage is predicted to cause a small rise in the atver age salinity of the basin, though the salinity of the coastal margins is projected to decrease. The concentration of dissolved oxygen is forccast to fall slightly, and there would be a small improvement in other water quality paraneters.

The scheme may inhibit the development of saltmarsh in the estuary due to the reduction of tide range though, with the exception of redshank (Tringa totanus), this estuary is not of national importance for sed bircis.

The Conwy is an important river for migratory salmonids. The design of the barrage therefore includes fish-passes 10

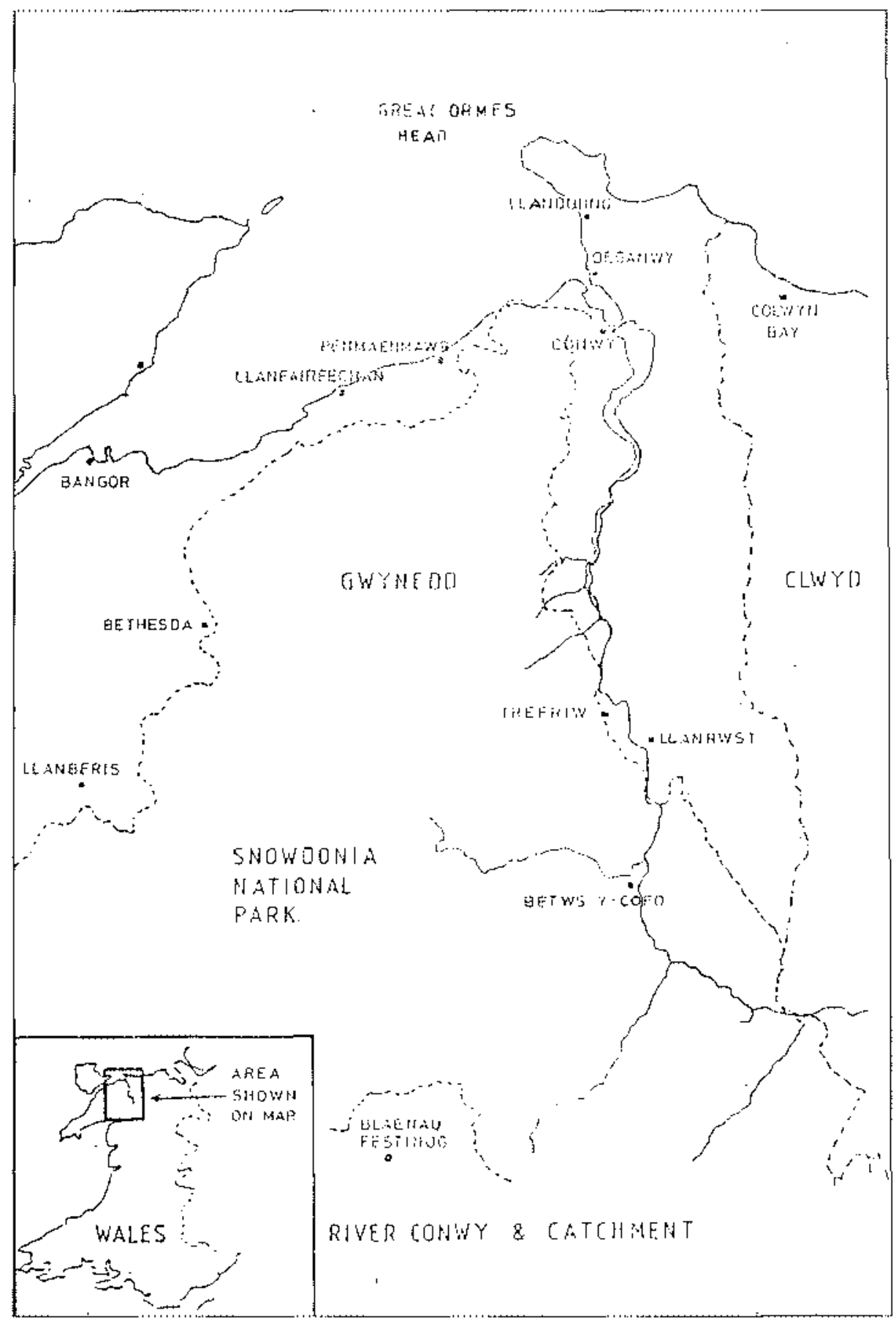

3. Conwy estuary. 
assist movement at specific phases of the tide. The design of these passes also allows them to assist emptying and refilling the basin. It is proposed that the ebb-flow turbines arc screened to prevent adult fish from passing through them.

The study concluded that there were no serious environmental constraints on the project and that the isstes which deserved more careftul attention and fesolution could be deatt with at the detailed design stage. The estuary is well suited to a tidal power scheme and this need have no permancht adverse effects.

\subsection{Duddon Barrage ( 4 f, fig. 4)}

The physical characteristics of this estuary are also similar to those outlined in Section 2. Its sediment regime is essentially sandy, ine sediments only occurring in sheltered areas protected from the currents and wave action. As at Conwy (and Rance), the amount of fine sediment occurting at sea bed level in this estuary is smatl, hence the levels of turbidity caused by its surpension are also small and localised.

The preferred location of the barage is also towards the seaward limil of the estuary due to the need to locate the tur-

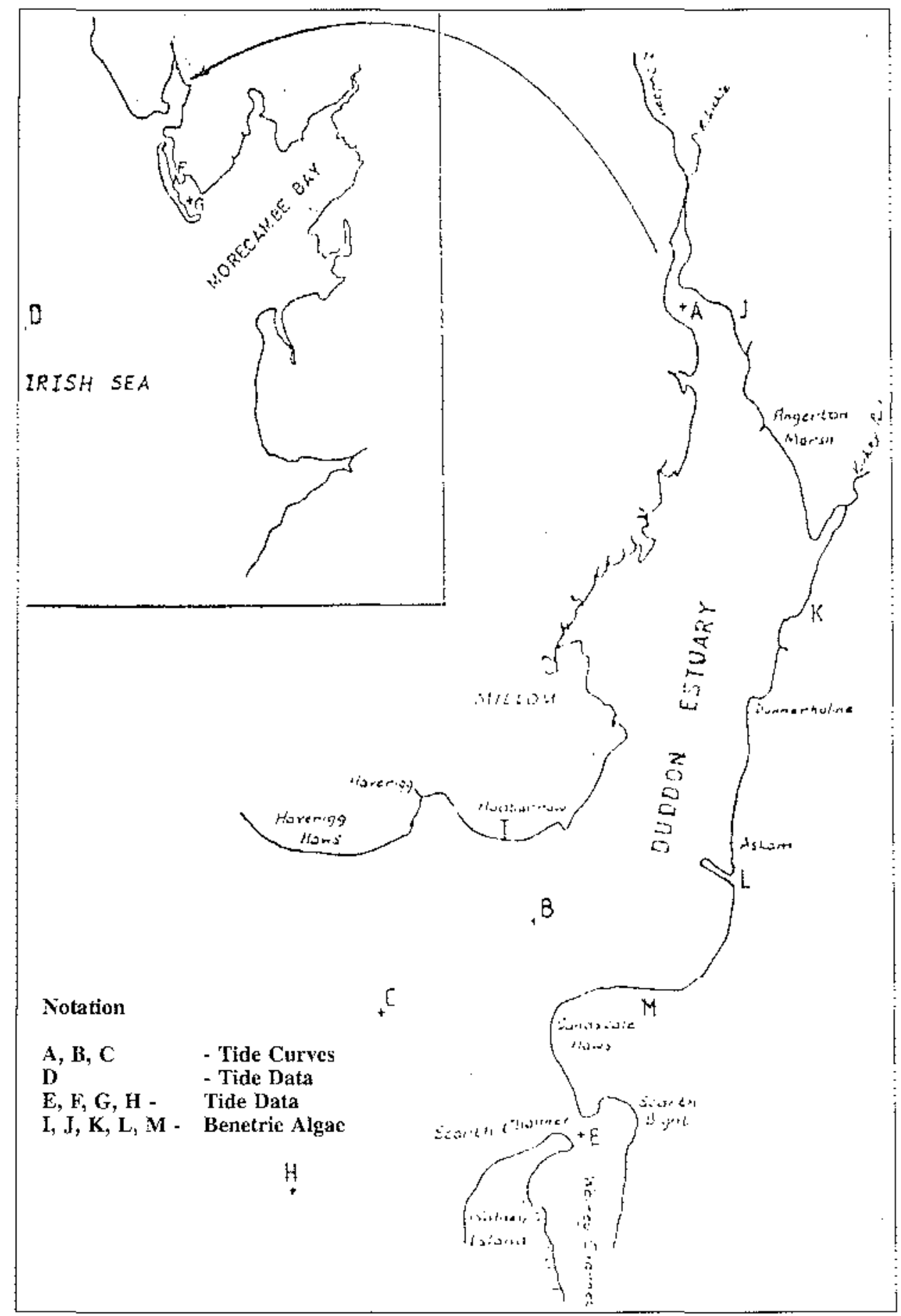

4. Duddon esiuary. 
bines in adequatcly deep water in positions closely connected with the sea. However, at this location the estuary is much wider than is needed for the turbines and sluices, hence much of the length of this barrage is necessarily made up of embankments, a large proportion of which would be in very shallow water.

Most of the area of this shallow estuary landward of the barrage is reduced to a central channel all low tide. The sands responsible for much of its geometry are mobilised by the currents, and the near absence of fine material in the sand means that they do not suppont a significant biomass. Only the protected areas which lie closer to high tide are significantly productive, and these would remain intertidal though differently exposed through the tide cycle.

The water quality of this estuary is generally good. The main contaminant in solution used to result from radioactive waste discharged from the nearby reprocessing plant at Sellaficld, but these levels are now much reduced. The river catchment is also not now at significant source of pollutants.

The estuary supports signiticant populations of sea-birds, mainly for feeding though some species also roost and nest in the extensive salimarshes which leature over much of its periphery. The effect of the modified tide range on the produclivity of these feeding grounds will depend on their ejevation within that regime and how its sediment composition will change.

Although the study was unable to reach a definitive position on this important issue there was reason to conclude that, because the currents would be less strong and the area more protected against the severe wave action which mobilises material, the fine sediment fraction and hence the capac- ity of the intertidal area to support invertebrates and therefore birds and fish could be expected to increase.

The study concluded that it was premature to decide whether special provision should be mete for fish passage through the buriage. Wher this study was being carricd out in the early 1990 s, the UK Government and other UK agencics were involved with detailed investigations into both fistín mortality in turbines and means to deter them from entering these machines. Since the results of that work were clearly likely to influence decisions on these topies, there was no case for speculating about them in the conclusions to the study.

However, the study clearly esitablished that the capilat cost of the Duddon Barrage would not make this a commercially viable project for power generation against the criteria which applied at that time (and since). Furthemore, the other facil. ities which it could provide for the area were insufficient to make up the considerable economic shortfatl.

\subsection{Loughor Barrage ( $\{5\}$, fig. 5 )}

The economics of the tidal power scheme proposed for this estuary were adversely affected by its small size (about $5 \mathrm{MW}$ ), and its prospects were further damaged by proposals to maintain a high water level in the basin so that the area could be used for recreation and amenily purposes.

The possibility of allowing the basin level to vary more during the winter in order 10 increstse the energy produced during those months was assessed but no agreement on this was reached.

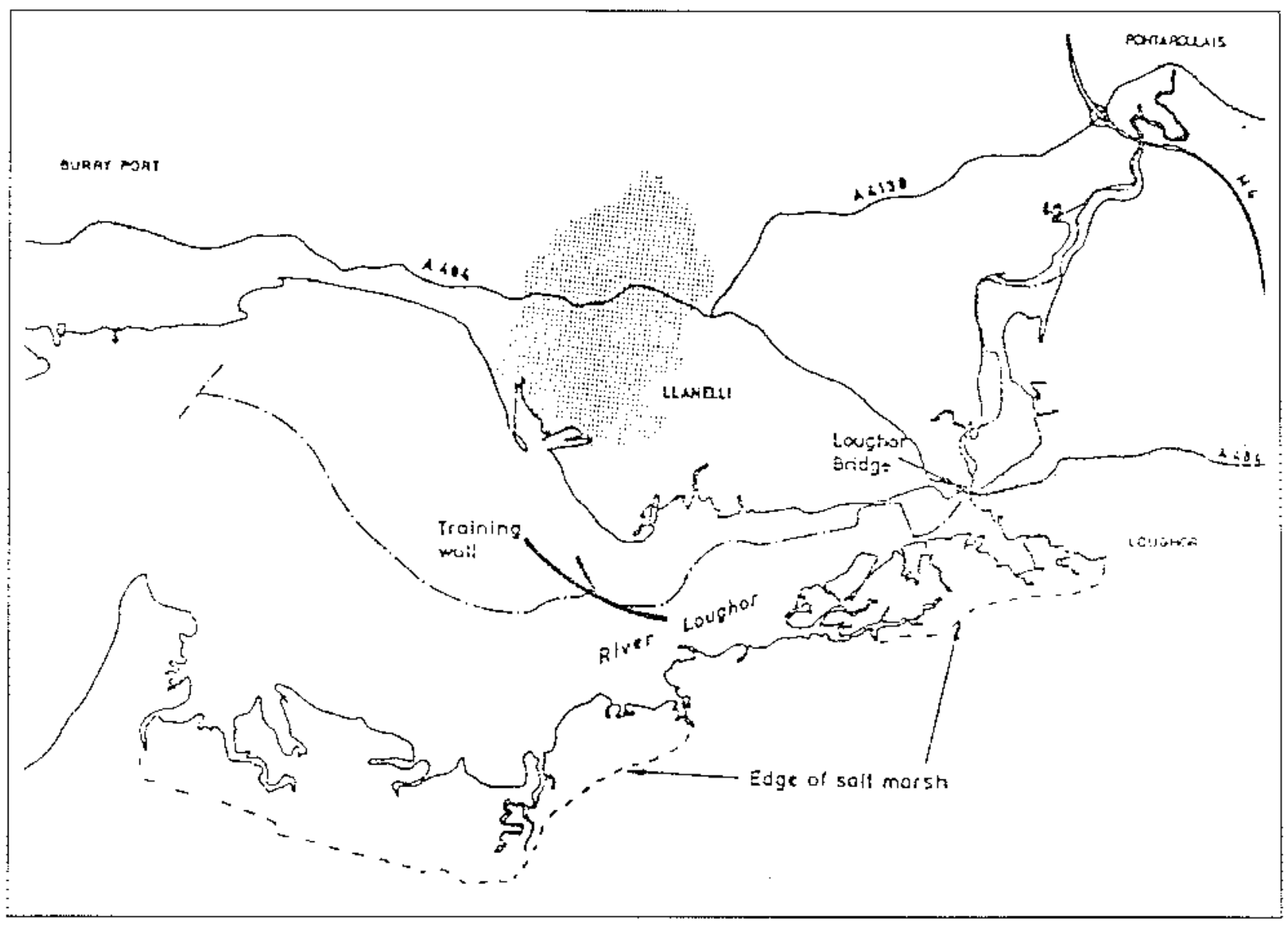

5. Loughor estuary. 
The environmental consequences of reducing the amounts of water passing across the barrage line were studied brielly. It was conchided that some adverse effects on water quatity in the basin area could arise but these and the prospects of increased sedimentation (sand) in the basin were not quantiticd in detail.

\subsection{Mersey Barrage ([6], fig. 6)}

The tidal power scheme proposed for the Mersey Estuary was and perhaps still is, the most likely to be constructed in the UK. It is large enough (700 MW) to benefit from economy of scale, and by beirg located in a relatively narrow $(1900 \mathrm{~m})$ waterway it is not burdened by the cost of unproductive embankments. Its layout therefore has much in common with the Rance project.

Furthermore, it was envisaged that by locating the scheme close to the middle of Liverpool (on the north side of the estuary) and Birkenhoad (on the south side), it would atso create significant infrastructure and amcnity benefits. One of the most difficult issures to resolve proved to be the effects of the scheme on commercial shipping in the estuary.

The site tinelly selected for the barrage sought a compronise between boln business and social issues and the particular ecological interests in the estuary which the schene was predicted to affect. As was noted in Section 2, by being well upstream from the mouth of the Mersey Estuasy, the sandy regime which, as elsewhere, features in the seaward reaches of this river is replaced by the more typical muddy conditions found in many river estuaries (including the upper reaches of the Rance Estuary above Pont St Jean).

As a result, this barrage would be located within a zone of high urbidity, where the water column is partially mixed (some satinity stratification) and where relatively lage inter- tidal areas significantly reduce the widh of the estuary at low ticte.

The water quality of the estuary is generally poor due mainly to the hervily industrialised catchment of the River Mersey and its tributaries. Large discharges of organic wastes, trace metals and micropollutants are the principal contaminants, one result of witich is low dissolved oxygen levels. The need to improve this situation has been accepted by the responsible authorities and major investments in remedial works are now being made.

The high turbidity of the estuary is only partly due to pollution. It is mainly caused by the erosive capacity of strong currents on the unconsolidated fine sedinents which (as noted above) are a feature of many inner estuaries. By generally reducing the currents (Section 2 above), the barrage would stabilise much of this material, allowing more sunlight to enter the water column, increasing phytoplankton productivity from its present very low level.

The poor water quatity of the estuary means that it does not support signifrcant fish populations, hence it is not an important spawning area or nursery ground for juvenile fish.

However, the estuary is of substantial national and international ornithological importance due to the presence of suitable sand and mudflats, utso saltmarshes. These support five wader and wildfowl species in internationally significant numbers, ranking the Mersey in the UK's top three for overwintering wildiowl.

The inner estuary is judged to warrant designation as a "Ramsar" site and an SPA under the EC's "Wild Birds Directive"

The proposed barrage is predicted to have a profound ihough by no means wholly unbencficial effect on this regime. The main physical changes are expected to improve the water quality, but some remedtal works to specilic discharges additionat to the general improvements now being made will be necessary to counter possible adverse elfects.

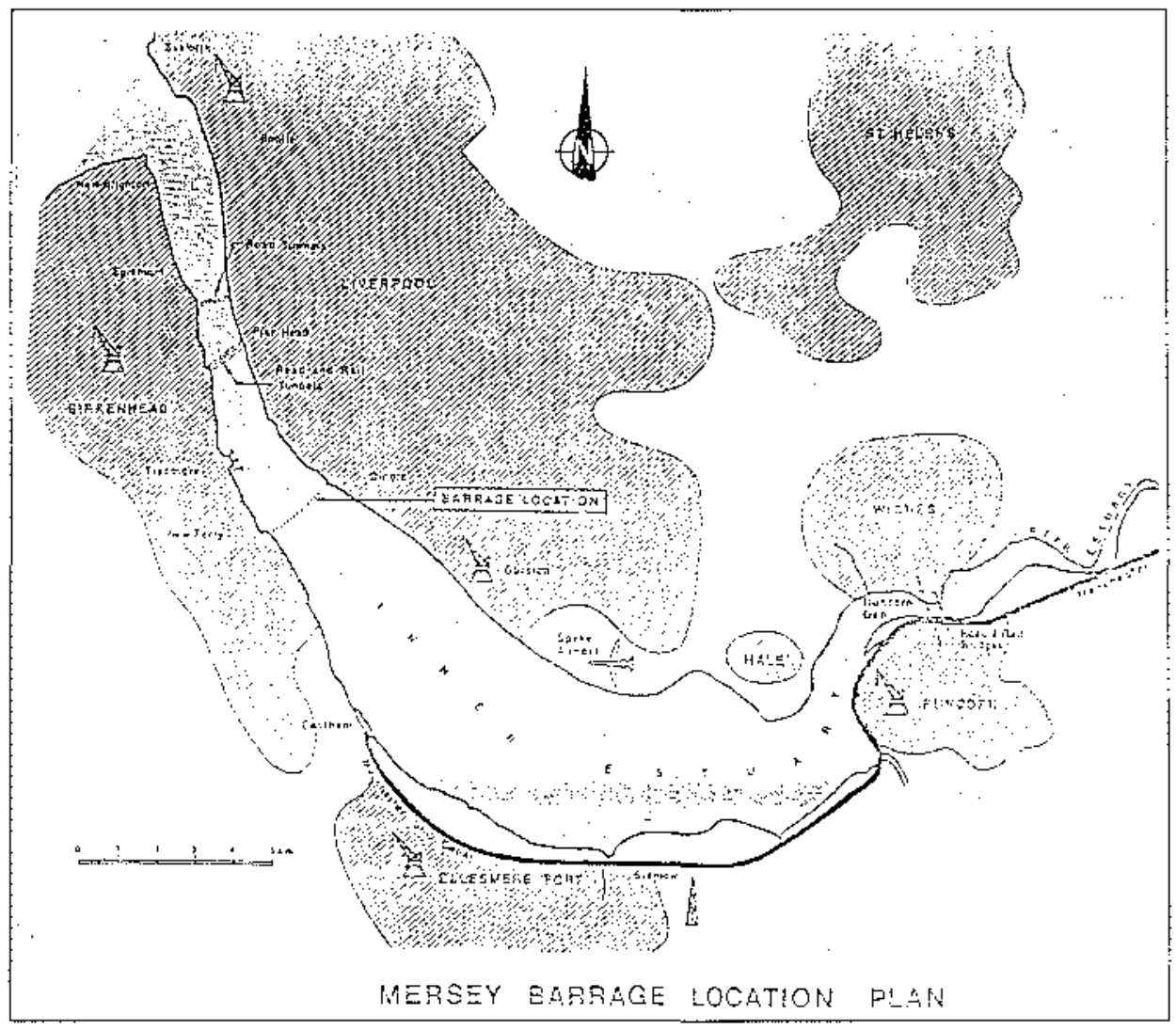

6. Location of the Mersey barrage. 
The major ecological implication of the barrage would be its anticipated impact on sea-birds. This is because inportent feeding areas would be mitue less accessible by the chaltge in tide regime, both the overell area and the time for which this is exposed being reduced. It is also anticipated that the foral composition of the saltmarshes could be changed with conseguences for fecting and grazing, and these areas would also become less available for roosting.

Much further research is needed to quantify the possible ecological changes identified in the initial siudies. The opportunities open for mitigation measures also remain to be assessed and optimised. However, no further work is a1 present being cartied out. Environmental considerations are one of the reasons why it is nor being pursued. Economic and infrastructure factors were atso prominent reasons for deferring further work.

\subsection{Wyre Barrage [7]}

The Wyre Estuary displays as simiter sand regime to that in the Conwy and Duddon Estuaries, which also occurs at the mouth of the Mersey Estuary. The proposal to locate a barrage close 10 its seaward limit means that, like Conwy and Dutdon, this would be within the sandy regime rather than upstream in the more muddy zone as for the hersey schene.

The hydrodynamic forces needed to keep the body of the Wyre Estuary clear of inne sediment are also sutficient to ensure that the sand is at times highly mobile, a situation which again resembles that at the other UK estuaries studied here, as well as at Rance. The barrage would reduce this movement and thereby produce a more stable and ecologically productive regine.

There are some concems about water quality in this cstuary but these are being dealt with as part of general improvements to the LK's coastal enviromment. The barrage would not is gnificantly worsen the situation which is expected to exist at such time as the project could be constructed.

The estuary is used by some migratory seabirds though these are generally not statistically important, and both salmon and sea trout also pass through in small numbers. The changes in foreshore submergence and invertebrate distribution may affect bird roosting and feeding but the study concluded that there are acceptable local options to any loss of existing opportunity.

Encertainty about the effects of turbine operation on fish passage led to the proposal that diversion systerns guiding fish to passes should be instalted.

As for the other schemes, small changes in salinity are expected snd the possibility that locally raised water tables might make it necessary to install pumps to drain affected area were again fealures of the solution proposed for this project.

Further work on this project was deferred due to the unacceptable cost at which it would produce energy.

\section{IV $\square$ CONCLLSIONS}

The cconomic conditions which existed in the UK at the turn of the 1980 s were principally responsible for the decision to curtail work on all of the tidal power projects reported here. The gap between the cost of producing electricity from the tides compared with that from the established sources was typically in the ratio $2: 1$, though the larger Mersey (and the even larger Severn) scheme came closer to being commercially viable.

Ecological issues received careful consideration in all of these studics, indeed it may be true 10 conclude that this uspect of tider power projects made nor progress during the 10-year period of the UK studies than any other: The fact that concens were voiced about the effects of each scheme conturms the percejved importance of estuartine environments for ecosysienrs. However, it must be equally true to conclude that the lack of proper evidence about these ceosystems and how they would be affected by the modified tidal regimes created by barrityes prevented many of these concerns from being deall with positively.

With the exception of the Mersey project (fig. 6), the four schemes covered in this Paper (and the Severn) are in estuarics which have much in common with Rance. Furthermore, by being close to the mouth of its estuary, the Rance Berrage is similarly located to these four proposed schemes. Their tide ranges ate all high and they are to varying degrecs: exposed to wave action.

However the UK studies made surprisingly little reference to experiences at Rance despitc their need for real informatior. I suspect that this was because it was quite wrongly believed that Rance had litte to offer because of the way in which the barrage was constructed and the fact that it is equipped with two-way turbines generally not favoured in tite $\mathrm{LK}$ in the $1980 \mathrm{~s}$.

If this is so it is totally at odds with my stimulating and beneitcial association with the Rance project, which dates from shortly after it was commissioned. In particular I have benelitted greally from many visits to and discussions with the staff of the Dinard Maritime Laboratory, without whose guidance we would be much the poorer.

In particular, I cannot conclude from the available evi. dence that tidal power inevitable damages estuarine ccosystems. Yes, there will be changes, and some features of the resulting enviromment will inevitably not please cveryone, especially those for whom any change will be a coluse for concern.

However, there is surely little reason to conclude from Rance that tidal power schemes cause scvere and intolerable damage to the environment. though in must be asked how the Ranee scheme would now be designed and operated to meet the environnertal criteria of the 1990s with the benelits of the knowledge which has come from it ?

Notwithstanding the lessons from Rance, we still have much to learn before we can have contidence in our predictions of the effects of tidal power schemes according to their designs and how they are constructed and operated. We cannot therefore expect conservation interests to accept our recommendations about the consequences of projects and how any adverse effects may be minimised and offset by nitifialion and compensatory measures.

Lnfortunately, in the LK at least there is litue imnediate sign that funding sources are available to support this work because the tides continue to be viewed as an expensive encrgy option. This was also the casc prior to the 1970 s, but once the situation reversed as a result of the oit "crises" there was immediate pressure for results and little time for considered thought and research. Tidal power will fail to play its fair role in meeting wortd energy demands until a more far-sighted vicw is taken.

The one bright prospect is that Rance continues 10 generate invaluable information. Where would tidal power be without it?

\section{ACKNOWLEDGEMENTS}

The author wishes to acknowledge the contribution made by the UK's Energy Technology Suppor Unit (ETSL), working on behaif of the UK Deparment of Trade \& Industry, for 
their efforts in co-ordinating the studies referred to in this Paper and for permission to reproduce information contained in the reports derived from those studies.

\section{REFERENCES}

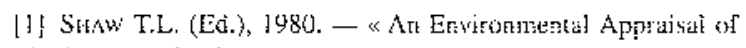
Tidil Power Stations (will particalar :eferetie to the Severn Barruge) 》. Pitrnan Press (Tirst published in sborened form in $1968)$.

|2| BtwiE \& PAkTERs, :987. - "The UK Potential for Tidal Energy from Sinall Estuaries ", ETSU Rpt. No. STP-4048 (P!).
3) T.H. Techno.ogy Lid., 1990. — « Corwy Estunry Feasibility Study of Tidil: Power \#, ETSL Rpt. No. TiD 4075.

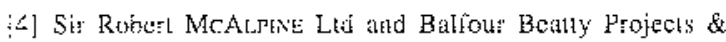
Engineering Lid, 1994. -... " Didddon Lstuary Tidd: Energy Barrage: Preliminary Feasibility Study ». ETSU Rpl. No. T/06/OH] 44/RLP.

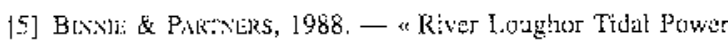
Scheme: A Feasibility Stady ", ETSL: Rpt. No. TID 4048-P2.

[6] Merscy Barrage Company, 1993. - "Tidat Power frorr the River Mersey: A liearsibility Study - Stage III Repori 》, ETSL; RpL. No. T/03/00140/REP.

[7] T.H. Technology Ltd, 199:. - «River wyre: Preliminary Fedsibility Study of Tidal Encrgy Barrage ane Road Crossing ", ETSU Rp?. NO. TID 4100. 